\title{
PERBANDINGAN KESETARAAN NILAI DOSIS SERAP BOLUS LILIN DAN CONFORMAL BOLUS TERHADAP JARINGAN LUNAK PADA PERENCANAAN TEKNIK RADIOTERAPI
}

\author{
${ }^{1}$ Yudha Aries Pratama, ${ }^{2}$ Muhammad Fadli \\ ${ }^{1}$ Mahasiswa semester VIII Jurusan TRO, Poltekkes Kemenkes Jakarta II. \\ ${ }^{2}$ Fisikawan Medis Rumah Sakit Siloam MRCCC Jakarta
}

\begin{abstract}
Backgroud: The purpose of this paper is to measure equality volue of wax bolus and conformal bolus againts soft tissue. This research is qualitative descriptive. This study is observed at Radiotherapy Department MRCCC Siloam Hospitals Semanggi. The methode of this research is measure, comparing a result and the research instrument used is electrometer and paper work to notice a result of measuement.

Methods: The device used is linear accelerator with type Clinac iX, ionization chamber adn electrometer. please note the room temperature and room preasure before measuring. Stack 10 plate of slab phantom with $1 \mathrm{~cm}$ thickness and $30 \times 30 \mathrm{~cm}^{2}$ wide on the linac table. After that put ionization chamber into the 10th slab phantom, add more 9 plate of slab phantom with same thickness and 1 plate of slab phantom with $0.5 \mathrm{~cm}$ thickness. Arrange the stack of slab phantom until the position in the middle of lasser in that room. Connect the ionization chamber with electrometer who locate in oprator room. In order to we can see the result at oprator room. Stacks a slab phantom, paraffin wax bolus and conformal bolus each having a thickness $0.5 \mathrm{~cm}$ alternately. Measuring 5 times in every material with $6 \mathrm{MV}$ and $15 \mathrm{MV}$ energy.
\end{abstract}

Result: The result is in $10^{-8} \mathrm{C}$. That result must be converted into absorb dose (cGy). Compare the result of wax bolus and conformal bolus against the result of slab phantom.

Keyword : Bolus, Absorb Dose

\section{Pendahuluan}

Dalam penyinaran radiasi pada kasus kanker payudara, biasanya menggunakan bolus sebagai alat bantu. Fungsi dari bolus itu sendiri adalah untuk kompensator distribusi dosis misalnya apabila diperlukan untuk menaikan dosis dipermukaan kulit. Bolus diletakan diatas kulit pasien dengan seluruh lapangan radiasi tertutup oleh bolus. Bolus juga dapat meningkatkan efek radiasi hambur kedalam kulit, radiasi hambur yang tercipta akibat interaksi foton dan bolus dapat meningkatkan dosis dipermukaan, jika bolus dilekatkan diatas kulit. Kejadian ini membuat dosis maksimum semakin dekat ke permukaan (khan F, 2010. Podgorsak, E. B, 2005.
Beyzdegoglu, M, 2010. Barton M, Graves F,. 2008. Barrett, A, et al, 2009.

Bolus adalah material pengganti yang nilai dosis serapnya setara dengan jaringan lunak, yang diletakan langsung diatas permukaan kulit pasien yang memiliki kontur tidak rata, sehingga menciptakan kontur yang rata. (khan F, 2010. Podgorsak, E. B, 2005. Beyzdegoglu, M, 2010. Barton M, Graves F,. 2008. Barrett, A, et al, 2009.

Di Indonesia biasanya menggunakan 2 jenis bolus, yaitu bolus yang terbuat dari lilin parafin dan bolus keras. Bolus lilin parafin biasanya digunaka pada penyinaran 
kanker payudara, sedangkan bolus keras biasanya digunakan pada penyinaran kanker pada bagian ekstremitas.

Pada saat ini ada bolus jenis baru yaitu conformal bolus, yang diperuntukan untuk menggantikan bolus lilin parafin. Bolus ini memiliki beberapa kelebihan, yaitu ketebalan dari bolus tersebut konstan, tidak perlu dibuat / dicetak dahulu seperti bolus yang terbuat dari lilin.

Penelitian ini bertujuan untuk mengetahui nilai dosis serap bolus lilin atau bolus conformal yang nilainya lebih mirip dengan nilai dosis serap slab phantom (material yang nilainya di anggap setara dengan nilai jaringan lunak tubuh manusia).

Sesuai dengan TRS-398 yang merupakan standar pengukuran untuk mendapatkan nilai dosis serap dalam satuan $c G y$.

Dimana CMR adalah hasil bacaan dari dosimeter yang telah dikalikan dengan nilai faktor koreksi yang mempengaruhi, dan $\mathrm{K}_{\mathrm{QQQ}}$ adalah faktor koreksi yang mengoreksi perbedaan antara referensi kualitas sinar $\mathrm{x} \mathrm{Q}_{0}$ dan kualitas $\mathrm{Q}$ aktual yang digunakan dan PDD (refdept) adalah persentase sinar $\mathrm{x}$ pada kedalaman refrensi.5 faktor koreksi terhadap suhu dan tekanan pada ruangan dengan persamaan.

Dimana telah diketahui $\mathrm{T}_{0}=20^{\circ} \mathrm{C}$ dan $\mathrm{P}_{0}=$ $1013.25 \mathrm{mbar}$. Setelah mendapatkan nilai faktor koreksi suhu dan tekanan ruangan, maka kita menghitung nilai faktor koreksi bacaam dari ionization chamber, yaitu dengan persamaan. Merupakan hasil bacaan dari ionization chamber yang telah kita ukur dan rata-ratakan sebelumnya dan $\mathrm{K}_{\text {elec }}$ (faktor koreksi electron) adalah 1 (Barrett, A, et al, 2009).

\section{Metode}

Tumpuk 10 buah slab phantom di atas meja pesawat linac, yang masing-masing slab phantom memiliki ketebalan $1 \mathrm{~cm}$ dan luas $30 \times 30 \mathrm{~cm}^{2}$. Setelah itu masukan ionization chamber kedalam slab phantom yang ke-10. Setelah itu, tambahkan lagi 9 buah slab phantom dengan ketebalan $1 \mathrm{~cm}$ dan 1 buah slab phantom dengan ketebalan $0.5 \mathrm{~cm}$. Atur tumpukan slab phantom tersebut agar berada pada tengah-tengah laser yang ada diruangan linac. Hubungkan ionization chamber dengan electrometer yang berada diruang oprator.

Sehingga kita bisa melihat hasil dari penyinaran dari ruang operator. Tumpuk slab phantom, bolus lilin dan bolus conformal yang masing-masing memiliki ketebalan $0.5 \mathrm{~cm}$ secara bergantian. Lakukan pengukuran sebanyak 5 kali pada setiap bahan dengan energy 6MV dan $15 \mathrm{MV}$.

\section{Hasil dan Pembahasan}

Dalam penelitian ini dilakukan perhitungan dosis serap terhadap slab phantom, bolus lilin parafin dan bolus conformal dengan menggunakan ionization chamber FC65-G yang diletakkan dengan SSD $100 \mathrm{~cm}$, MU 100 dan luas lapangan $10 x 10 \mathrm{~cm}^{2}$. Dalam perhitungan energy yang digunakan adalah $6 \mathrm{MV}$ dan $15 \mathrm{MV}$. Suhu diruangan adalah $19.5^{\circ} \mathrm{C}$ dan tekanan diruangan adalah 1007 mbar pada saat pengambilan data Setelah dilakukan pengukuran nilai dosis serap terhadap slab phantom dengan menggunakan energi $6 \mathrm{MV}$ dan $15 \mathrm{MV}$ dan masing-masing energi dilakukan sebanyak 5 kali.

Tabel 1. Hasil pengukuran slab phantom

\begin{tabular}{|c|c|c|}
\hline \multirow{2}{*}{ Pengukuran } & \multicolumn{2}{|c|}{ Tegangan $\left(10^{-8} \mathrm{C}\right)$} \\
\cline { 2 - 3 } & $6 \mathrm{MV}$ & $15 \mathrm{MV}$ \\
\hline $\mathrm{R} 1$ & 1.388 & 1.607 \\
\hline R2 & 1.387 & 1.607 \\
\hline R3 & 1.386 & 1.608 \\
\hline R4 & 1.387 & 1.607 \\
\hline R5 & 1.388 & 1.607 \\
\hline Rata-rata & 1.387 & 1.6072 \\
\hline
\end{tabular}

Setelah dilakukan pengukuran nilai dosis serap terhadap bolus lilin dengan menggunakan energi $6 \mathrm{MV}$ dan $15 \mathrm{MV}$ dan masing-masing energi dilakukan sebanyak 5 kali pengukuran didapatkan hasil seperti pada Tabel 2. 
Tabel 2 hasil pengukuran bolus lilin

\begin{tabular}{|c|c|c|}
\hline \multirow{2}{*}{ Pengukuran } & \multicolumn{2}{|c|}{ Tegangan $\left(10^{-8} \mathrm{C}\right)$} \\
\cline { 2 - 3 } & $6 \mathrm{MV}$ & $15 \mathrm{MV}$ \\
\hline $\mathrm{R} 1$ & 1.386 & 1.606 \\
\hline $\mathrm{R} 2$ & 1.386 & 1.606 \\
\hline $\mathrm{R} 3$ & 1.386 & 1.606 \\
\hline R4 & 1.385 & 1.605 \\
\hline R5 & 1.386 & 1.606 \\
\hline Rata- & 1.3858 & 1.6058 \\
\hline rata & & \\
\hline
\end{tabular}

\section{Analisis Statistik}

Setelah dilakukan pengukuran nilai dosis serap terhadap bolus conformal dengan menggunakan energi $6 \mathrm{MV}$ dan $15 \mathrm{MV}$ dan masing-masing energi dilakukan sebanyak 5 kali pengukuran didapatkan hasil seperti pada Tabel 3

Tabel 3. Hasil pengukuran bolus conformal

\begin{tabular}{|c|c|c|}
\hline \multirow{2}{*}{ Pengukuran } & \multicolumn{2}{|c|}{ Tegangan $\left(10^{-8} \mathrm{C}\right)$} \\
\cline { 2 - 3 } & $6 \mathrm{MV}$ & $15 \mathrm{MV}$ \\
\hline R1 & 1.379 & 1.601 \\
\hline R2 & 1.378 & 1.600 \\
\hline R3 & 1.379 & 1.600 \\
\hline R4 & 1.379 & 1.601 \\
\hline R5 & 1.380 & 1.600 \\
\hline Rata-rata & 1.379 & 1.6004 \\
\hline
\end{tabular}

Setelah didapat hasil pengukuran slab phantom, bolus lilin dan bolus conformal maka dilakukan perhitungan faktor koreksi terhadap suhu dan Maka didapatkan factor koreksi suhu dan tekanan ruangan adalah 1.0045.

Setelah mendapatkan nilai faktor koreksi suhu dan tekanan ruangan, maka kita menghitung nilai dimana $\mathrm{M}$ merupakan hasil bacaan dari ionization chamber yang telah kita ukur dan rata ratakan sebelumnya dan (faktor koreksi electron) adalah 1 (Barrett, A, et al, 2009).

Tabel 4 Hasil perhitungan CMR

\begin{tabular}{|c|c|c|}
\hline Bahan & Energi 6MV & $\begin{array}{c}\text { Energi } \\
15 \mathrm{MV}\end{array}$ \\
\hline Slab Phantom & $\begin{array}{c}1.393 \times 10^{-} \\
{ }^{8} \mathrm{C}\end{array}$ & $\begin{array}{c}1.614 \times 10^{-} \\
{ }^{C} \mathrm{C}\end{array}$ \\
\hline $\begin{array}{l}\text { Bolus Lilin } \\
\text { Parafin }\end{array}$ & $\begin{array}{c}1.3852 \times 10^{-} \\
{ }^{8} \mathrm{C}\end{array}$ & ${ }^{8} \mathrm{C}$ \\
\hline Bolus & $1.6076 \times 10^{-}$ \\
Conformal & ${ }^{8} \mathrm{C}$ & $1.613 \times 10^{-}$ \\
& & ${ }^{8} \mathrm{C}$ \\
\hline
\end{tabular}

Setelah mendapatkan hasil CMR maka kita dapat menghitung faktor kalibrasi dosis serap pada air dan nilainya tersebut, faktor koreksi respon dari ionization chamber pada energy tertentu. Telah diketahui nilai $\mathrm{K}_{\mathrm{Q}, \mathrm{Q}}$ pada energy $6 \mathrm{MV}=0.9958$ dan pada energy $15 \mathrm{MV}=0.9807$. Nilai PDD (ref. dept) pada energy $6 \mathrm{MV}$

Pada tabel 4. merupakan hasil perhitungan nilai CMR pada bahan slab phantom, bolus lilin dan bolus conformal dengan energy $6 \mathrm{MV}$ dan Nilai $\mathrm{D}_{\mathrm{w} . \mathrm{e}}$ diatas merupakan hasil perhitungan konversi nilai muatan listrik menjadi satuan dosis serap (cGy) pada slab phantom dengan energy $15 \mathrm{MV}$ yang didapatkan dengan persamaan yang 6MV. Maka didapat nilai $D_{\text {W.e }}$ slab phantom pada energy 6MV adalah 100.01 $c G y$. Telah dilakukan perhitungan konversi nilai muatan listrik ke satuan dosis serap $(c G y)$ dengan cara yang sama pada bahan bolus lilin dan bolus conformal dengan energy 6MV dan 15MV. Maka didapatkan hasil nilai dosis serap $(c G y)$ seperti yang terlihat pada table 5 .

Table 5 Hasil perhitungan $\mathrm{D}_{\mathrm{W}, \mathrm{Q}}$

\begin{tabular}{|c|c|c|}
\hline \multirow{2}{*}{ Bahan } & \multicolumn{2}{|c|}{ Dosis serap pada energy : } \\
\cline { 2 - 3 } & $6 \mathrm{MV}$ & $15 \mathrm{MV}$ \\
\hline $\begin{array}{c}\text { Slab Phantom } \\
\text { Bolus Lilin } \\
\text { Parafin }\end{array}$ & $99.45 c G y$ & $98.17 c G y$ \\
\hline $\begin{array}{c}\text { Bolus } \\
\text { Conformal }\end{array}$ & $99.94 c G y$ & $98.50 c G y$ \\
\hline
\end{tabular}


Tabel 5 merupakan hasil dari perhitungan dosis serap pada slab phantom, bolus lilin dan bolus conformal dengan energy $6 \mathrm{MV}$ dan 15MV. Setelah didapatkan nilai dosis serap pada masing- masing bahan pada tiap energi, kita bisa membandingkan kemampuan dosis serap bolus lilin dan conformal bolus terhadap nilai dosis serap slab phantom. Cara membandingkannya dengan cara menghitung selisih nilai dosis serap slab phantom terhadap nilai dosis serap bolus lilin dan menghitung selisih nilai dosis slab phantom terhadap nilai dosis serap bolus conformal. Setelah membandingkannya, kita dapat melihat nilai dosis serap bolus lilin atau bolus conformal yang lebih mendekati nilai dosis serap jaringan lunak. Hasil tersebut dapat dilihat dengan caa melihat selisih nilai yang paling sedikit. Hasil perbandingan tersebut dapat dilihat pada tabel 6 .

Tabel 6 Perbandingan nilai dosis serap

\begin{tabular}{|c|c|c|}
\hline $\begin{array}{c}\text { Perbandingan nilai } \\
\text { dosis serap }\end{array}$ & $\begin{array}{c}\text { Perbedaan dosis serap } \\
\text { pada energy }\end{array}$ \\
\cline { 2 - 3 } & $6 \mathrm{MV}$ & $15 \mathrm{MV}$ \\
\hline $\begin{array}{c}\text { Slab Phantom - bolus } \\
\text { lilin paraffin }\end{array}$ & $0.56 c G y$ & $0.41 c G y$ \\
\hline $\begin{array}{c}\text { Slab Phantom - Bolus } \\
\text { Conformal }\end{array}$ & $0.07 c G y$ & $0.08 c G y$ \\
\hline
\end{tabular}

Tabel 6 menunjukan selisih nilai dosis serap slab phantom terhadap nilai dosis serap bolus lilin dan selisih nilai dosis serap slab phantom terhadap nilai dosis serap bolus conformal pada energy 6MV dan 15MV.Hasil pengukuran yang didapat sangat konsisten pada masing-masing bahan dan pada tiap energy. Hasil pengukuran pada slab phantom pada energy 6MV didapatkan hasil antara $1.386-1.388 \times 10^{-8} \mathrm{C}$, hanya memiliki selisih terjauh yaitu Sedangkan pada energy 15MV hasil yang didapatkan adalah 1.607 $1.608 \times 10^{-8} \mathrm{C}$, hanya memiliki selisih terjauh yaitu 0.001 . Hasil pengukuran bolus lilin pada energy $6 \mathrm{MV}$ didapatkan antara $1.379-1.380 \times 10^{-8} \mathrm{C}$, hanya memili selisih terjauh yaitu 0.002 . sedangkan pada energy $15 \mathrm{MV}$ didapatkan hasil $1.600-1.601 \times 10^{-8} \mathrm{C}$, hanya memiliki selisih terjauh yaitu 0.001. Pada pengukuran bolus conformal dengan energy 6MV didapatkan hasil antara $1.385-1.386 \times 10^{-8} \mathrm{C}$, hanya memiliki selisih terjauh yaitu 0.001 dan pada energy $15 \mathrm{MV}$ didapatkan hasil antara 1.605 - 1. Dilihat dari data diatas yang didapat pada masing-masing

\section{bahan dan pada tiap}

energy adalah konsisten, tidak memiliki perbedaan yang cukup jauh pada setiap pengukuran pada bahan dan energy yang sama.

Dari hasil pengukuran yang terlihat pada tabel 6 , terlihat bahwa nilai dosis serap pada bolus conformal lebih sedikit selisihnya dibandingkan dengan nilai dosis serap bolus lilin terhadap slab phantom. Nilai dosis serap bolus conformal hanya memiliki selisih $0.07 c G y$ dengan nilai slab phantom pada energy 6MV dan selisih 0.08 $c G y$ pada energy $15 \mathrm{MV}$. Sedangkan nilai dosis serap bolus lilin terhadap slab phantom memiliki selisih yang lebih lebar, yaitu $0.56 c G y$ pada energy $6 \mathrm{MV}$ dan selisih $0.41 c G y$ pada energy $15 \mathrm{MV}$, jika semakin kecil perbedaan nilai dosis serap pada suatu bahan terhadap jaringan lunak tubuh manusia, itu berarti bolus tersebut memiliki nilai dosis serap yang mirip dengan nilai dosis serap jaringan tubuh manusia

\section{Simpulan}

Nilai dosis serap pada bolus conformal lebih sedikit selisihnya dibandingkan dengan nilai dosis serap bolus lilin terhadap slab phantom. Hal itu memiliki arti bahwa nilai dosis serap bolus conformal lebih mirip dengan nilai dosis serap jaringan lunak tubuh manusia dibandingkan dengan nilai dosis serap bolus lilin.

\section{Daftar Pustaka}

Andreo, P. (2004). Absorbed Dose Determination in external Beam Radiotherapy: An International Code of Practice for Dosimetry Based on Standards of Absorbed Dose to Water. Vienna: IAEA.

Barton M, Graves F. (2008). Radiotherapy Risk Profile, Technical Manual. Bern: World Health Organization. 
Barrett, A., Dobbs, J., Morris, S., Roques, T. (2009). Practical Radiotherapy Planning. London: Hodder Arnold.

Beyzdegoglu, M. (2010). Basic Radiation Oncology. Berlin: Springer.

Khan, F. (2010). The Physics of Radiation Therapy. Sydney: Williams \& Wilkins.

Podgorsak, E. B. (2005). Radiation Oncology Physics: A Handbook for Teachers and Students. Vienna: IAEA. 